\title{
Interactive Technologies in Electronic Educational Resources
}

\author{
Tatyana Ivanovna Anisimova ${ }^{1} \&$ Lyubov Alekseevna Krasnova ${ }^{1}$ \\ ${ }^{1}$ Kazan (Volga region) Federal University, Republic of Tatarstan, Russia \\ Correspondence: Tatyana Ivanovna Anisimova, Kazan (Volga region) Federal University, Elabuga Institute, 89, \\ Kazan Street, Elabuga 423600, Republic of Tatarstan, Russia.
}

\author{
Received: October 15, 2014 Accepted: November 12, 2014 Online Published: January 28, 2015 \\ doi:10.5539/ies.v8n2p186 URL: http://dx.doi.org/10.5539/ies.v8n2p186
}

\begin{abstract}
Modern professional education in the transition to a tiered system of specialists training is focused not on the transfer of ready knowledge but on teaching to find this knowledge and to apply them in situations close to the professional conditions. The educational process, relying on use of interactive methods of teaching, which is organized with involvement of all students of the group, without exception, in the learning process, facilitates this. The problem of introduction of interactive forms of teaching in the educational process of higher education institutions is considered in the article, the experience of use of interactive technologies in electronic educational resources of physico-mathematical faculty of the Elabuga Institute of the Kazan (Volga region) Federal University is presented. On the basis of the received results the importance of the developed electronic educational resources in the context of the competence-based approach to training of bachelors, increase of their competitiveness is proved.
\end{abstract}

Keywords: interactive forms, educational process, distance learning, electronic educational resource, educational standard

\section{Introduction}

The concept of modernization of the higher education determines the following main characteristics of a graduate of the higher education institution meeting the modern requirements: competitiveness at the labour market, competence, responsibility, ability to effective work by profession at the level of the international standards, willingness for continuous professional growth, social and professional mobility.

Formation of these qualities is facilitated by introduction of interactive forms of teaching in the higher education institution, where the main role in the educational process is played by a student who can be not just definitely informed but also is capable to acquire practical skills and abilities, to absorb the gained knowledge, arrange them in a logical chain, organize them, make them an organic part of world outlook, personal feeling. The effectiveness of high-quality education is achieved by activization of a student himself.

Interactive teaching is a special form of organization of cognitive activity. It means quite concrete and predictable goals. The goal is to create a comfortable learning environment in which a student or listener feels his success, his intellectual capacity what makes the educational process itself productive.

In other words, interactive teaching is, first of all, dialogue teaching during which interaction between a student and a teacher, between students is carried out.

When using interactive forms the role of a teacher sharply changes, stops being central, he only regulates the process and is engaged in its general organization, prepares the necessary tasks in advance and formulates questions or subjects for discussion in groups, gives consultations, controls time and order of fulfillment of the drawn-up plan.

The main advantages of interactive forms of teaching are widely known:

- activization of active-cognitive and cogitative activities of students;

- involvement of students in the educational process, acquisition of new material by not as passive listeners but as active participants;

- development of analysis skills and critical thinking;

- increase of motivation for studying a discipline; 
- creation of favourable atmosphere at studies;

- development of communicative competences of students;

- reduction of a share of traditional classwork and increase of volume of a student's self-guided work;

- development of skills of mastering modern technical devices and technologies of information processing;

- formation and development of ability to find information independently and to determine a level of its reliability, etc.

The review of interactive methods of teaching, possibilities and practical value of use of these methods in the system of higher professional education are considered in works of Guschin (2012), Kurysheva (2009), Fischer (2010), Reutova (2012), etc. It is noted in these works that when using interactive methods a learner becomes a full participant of the perception process, his experience serves as the main source of educational cognition. A teacher's activity gives way to learners' activities and a teacher's task becomes creation of conditions for their initiatives.

The strengths of interactive (electronic) learning are specified in the article (Shaidullin et al., 2014): flexibility, personalisation, adaptability for students with various abilities and demands, etc.

Despite a rather large number of researches in introduction of interactive forms of teaching (Educational Benefits, 1998; Moore \& Anderson, 2012; Soekartawi et al., 2002), there are questions which require solution: use of distance forms of learning allowing constant interaction between the participants of learning regardless of their geographical remoteness from each other, complex use of various forms, means and methods of interactive teaching in organic combination with traditional ones.

\section{Main Part}

In the Federal State Educational Standards of Higher Professional Education of Training of Bachelors and Masters it is formulated: "Realization of competence-based approach must provide the wide use of active and interactive forms of conducting studies in the educational process (computer simulations, business and role plays, case studies, psychological and other trainings) in combination with out-of-class work for formation and development of the professional skills of learners. When implementing Bachelor Degree Programme and Master's Programme electronic learning and distance educational technologies may be applied" (The Federal State Educational Standard, 2009).

Distance learning takes a special place in interactive forms of teaching which must provide:

- modern level of specialists training;

- introduction of the new information and communication technologies (ICT) in the educational process, the best practices on use of distance learning of domestic and foreign educational institutions;

- creation of favourable conditions for educational methodical activities of teaching personnel;

- increase of a share of self-guided work of students during studying a discipline;

- replenishment of a bank of the electronic educational resources (EER).

The problem of use of distance learning as a form of education is actively discussed in the Russian and foreign scientific and methodical literature (Andreyev, 2003; Polat, 2006; Khutorskoy, 2001; Burns, 2011; Stephens, 2007). The possibilities and essential characteristics of distance education, use of EER are considered in these works.

Considering EER it is necessary to note that, on the one hand, it is a combination of graphic, text, digital, speech, musical, video, photo and other information as well as printed documentation of a user. The resource can be operated on any electronic medium or be placed in a computer network. On the other hand, it is a software and information component of the educational system the users of which are teachers, students and administration of educational institution.

Regardless of the contents and volume three main users' demands for EER can be allocated: adequacy of the contents, effectiveness of a form of presentation; economic effectiveness.

Adequacy of the contents means compliance to the state educational standard; fullness of presentation of the educational material sufficient for studying a discipline (discipline section); support of different forms of education (tuition by correspondence and full-time tuition, individual and collective); support of different types of studies (studying theoretical material, practical and laboratory works), support of different forms of control of knowledge (mid-term examination, final assessment, self-assessment); accounting of the latest trends in science 
and technology.

Effectiveness of a form of presentation information includes the following requirements: simplicity and convenience of application, ergonomics, support of a student's activity, ensuring communication with a teacher and fellow students, protection against destruction, opportunity of restoration of the lost information. Economic effectiveness of the educational system largely depends on such EER properties as long term of operation, possibility of modernization in the process of operation, low prime cost and price, reasonable configuration of necessary technical and all-system means.

Many of the listed requirements are conflicting and are difficult to be combined, therefore, development of EER is a complicated problem solved by a group of experts of a different profile.

To the innovative qualities of EER are referred:

1) Providing all the components of the educational process:

- receiving information;

- practical course;

- $\quad$ assessment (control of educational achievements).

2) Interactivity which provides sharp expansion of a sector of self-guided educational work through the use of active-

activity forms of learning.

3) Opportunity of remote (distance) full learning.

Full value in this case means realization of such types of educational activities "at home" (in an Internet cafe, in the library, eventually-out of classroom) which could be conducted only at University before: study of new material on a subject basis, laboratory experiment, current control of knowledge with assessments and conclusions and also many other things, up to collective educational work of remote users (Sarafanov, 2006).

\section{Methods}

At the Elabuga Institute of the Kasan Federal University (EI KFU) the programmes of training and introduction of electronic educational resources in the educational process are successfully realized in recent years. Today the electronic versions of working programmes, methodical instructions on all studied disciplines, provided practically for each training direction by the Educational Standard, are available to any student.

\subsection{Interactive Technologies}

For students of EI KFU, trained in the direction 051000.62-Professional education (by branches) is organized studying a list of subjects with use of interactive technologies. The Federal State Educational Standard of a bachelor training, in which it is specified that share of the studies, given in interactive forms, must make not less than 30 percent of classroom studies, demands it (The Federal State Educational Standard, 2009). Depending on the goal and opportunities of filling of the studied disciplines with interactive forms, their structure and contents include:

- traditional forms of studies;

- lectures and practical course with use of multimedia means;

- hybrid studies (partially in classroom, partially interactively);

- virtual laboratory works on different sections of Physics which allow to conduct researches and observations which cannot be conducted, received and analysed using the standard physical equipment;

- virtual excursions;

- interactive lectures on the following subjects: lecture-conversation "Function and Its Main Properties"; lecture-discussion "Problems Leading to a Notion of a Derivative"; problem lecture "Problems Leading to a Notion of the Differential Equations", etc.;

- innovative elements of interactive forms: brain storm, solution tree, work in small groups on subjects: "Application of Differential Calculus in Economics (Power Engineering)", "Integral Calculus in Economics (Power Engineering)" at studies;

- creative tasks which make the contents, a basis of any interactive method. The creative task gives sense to learning, motivates learners. An unknown answer and opportunity to find his own "correct" solution, based on the personal experience and on a colleague's experience, friend, allow to create a foundation for 
cooperation, co-learning, communication of all participants of the educational process including a teacher. The choice of a creative task is a creative task in itself also for a teacher as it is required to find such a task which would match the following criteria:

- has no a definite and curt answer or solution;

- is practical and useful for students;

- $\quad$ is connected with learners' lives;

- causes interest of students;

- $\quad$ serves learning goals as much as possible.

In the working programmes of disciplines the used interactive forms of teaching are shown in Table 1.

Table 1. The scheme of the used interactive forms of teaching in the working programmes

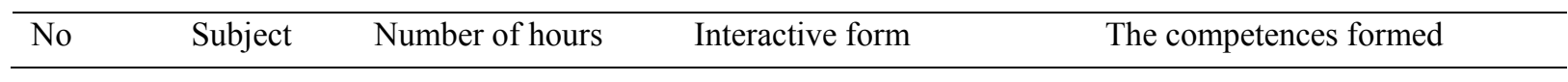

Within the programme of optimization of the educational process the electronic educational resources, which assume independent study of the material, put on a platform "Tulpar" of a system of distance learning of KFU, are developed on the basis of development and introduction of distance modules in the educational process. On the platform LMS MOODLE - a learning management system which allows to create the distance learning courses (network courses) including all the necessary educational, subsidiary and controlling materials (or links to them) and also methodical instructions according to the working programme of a discipline-is used.

To the main opportunities of LMS MOODLE system are referred:

- ample opportunities on putting and updating of educational and methodical supply of an educational course;

- tools for distance consultation of learners by means of forums;

- opportunity of regular monitoring of listeners' works by means of viewing of statistics of attendance;

- wide use of an element of the course "Task" to which students attach files with the done test;

- the system can be used both for distance and full-time tuition (Ustyugova, 2011).)

- The system of distance learning LMS MOODLE has tools for control of knowledge which has the following functionality:

- automatic control of testing results (with the help of certain settings, during of test creating, a teacher can define a necessity of viewing of results by learners independently or, on the contrary, not display them);

- opportunity of correction and assessment of the done tasks, exercises, papers, essays, projects (a teacher has an opportunity to comment on a learner's each answer when checking (e.g., to leave his remarks) in order that a student should understand for what such number of points or grades were given to him);

- providing with fast feedback (after checking tasks a student as well as a teacher can know the results of the done work);

- formation of protocols-reports on the done tasks, practical works;

- for each task a teacher can create his own grading scale, for example, standard (a 5-point, a 100-point, pass /fail, etc.) and assess results of learners' works at his own discretion.

\subsection{Application of EER in the Educational Process}

The teachers of the Faculty of Physics and Mathematics of EI KFU have developed and tested EER in the following training directions (Table 2): 
Table 2. Electronic educational resources of the Faculty of Physics and Mathematics of EI KFU

\begin{tabular}{|c|c|c|c|}
\hline Training direction & Discipline & Course & Authors \\
\hline $\begin{array}{l}051000.62 \\
\text { "Professional }\end{array}$ & \multirow[t]{3}{*}{ Mathematics } & $\begin{array}{l}\text { Differential calculus for functions of one and } \\
\text { several variables }\end{array}$ & Anisimova T. I. \\
\hline education", branches & & Mathematics_Introduction to Analysis & Anisimova T. I. \\
\hline $\begin{array}{l}\text { Energetics, } \\
\text { Economics } \\
\text { Management }\end{array}$ & & Mathematics_Differential equations & Anisimova T. I. \\
\hline 051000.62 & \multirow[t]{2}{*}{ Physics } & \multirow[t]{2}{*}{ Molecular Physics and Thermodynamics } & \multirow[t]{2}{*}{ Krasnova L. A. } \\
\hline $\begin{array}{l}\text { "Professional } \\
\text { education", branch } \\
\text { Energetics }\end{array}$ & & & \\
\hline \multirow[t]{2}{*}{$\begin{array}{l}\text { Advanced Teachers } \\
\text { Training Course }\end{array}$} & \multirow[t]{2}{*}{ Mathematics } & $\begin{array}{l}\text { The content and organization of teaching } \\
\text { Mathematics at the profile and pre-profile } \\
\text { levels }\end{array}$ & $\begin{array}{l}\text { Anisimova T. I. } \\
\text { \& Gilmullin M. } \\
\text { F. }\end{array}$ \\
\hline & & $\begin{array}{l}\text { New approaches and principles of teaching } \\
\text { Mathematics (activity approach) }\end{array}$ & $\begin{array}{l}\text { Anisimova T. I. } \\
\text { \& Gilmullin M. } \\
\text { F. }\end{array}$ \\
\hline \multirow[t]{2}{*}{$\begin{array}{l}\text { Advanced Teachers } \\
\text { Training Course }\end{array}$} & \multirow[t]{2}{*}{ Physics } & \multirow[t]{2}{*}{$\begin{array}{l}\text { Psycho-pedagogical conditions of development } \\
\text { of students ' interest in studying Physics }\end{array}$} & $\begin{array}{l}\text { Krasnova L. A. } \\
\&\end{array}$ \\
\hline & & & Sabirova F. M. \\
\hline \multirow[t]{3}{*}{$\begin{array}{l}\text { Advanced Teachers } \\
\text { Training Course }\end{array}$} & \multirow[t]{3}{*}{$\begin{array}{l}\text { Mathematics } \\
\text { and Physics }\end{array}$} & \multirow[t]{3}{*}{$\begin{array}{l}\text { Updating the content of physico-mathematical } \\
\text { education in the transition to a system-activity } \\
\text { approach }\end{array}$} & $\begin{array}{l}\text { Anisimova T. I. } \\
\& \text { Gilmullin M. } \\
\text { F. }\end{array}$ \\
\hline & & & Krasnova L. A. \\
\hline & & & Sabirova F. M. \\
\hline
\end{tabular}

Experience of organization and holding the distance advanced training courses of teachers with use of EER is presented in the article Krasnova and Anisimova (2013) by us in which: the goal, objectives of distance courses have been determined and developed and their structure has been described. On the basis of the received results the following advantages of distance courses have been specified:

- a teacher is given an opportunity of professional improvement without interruption from the primary activity and obtaining a certificate of the accepted sample;

- there a process of individualization of learning occurs;

- a process of professional development becomes more open, continuous and flexible;

- free and continuous entry onto the courses, choice of individual programmes, terms and rate of learning are possible;

- $\quad$ equal conditions for professional development for city and rural pedagogical workers are created;

- expenses from the municipal budget for financing advanced training courses of teachers are cut down.

We will stop on the experience of application of interactive technologies in EER for training of bachelors of professional education on the example of a discipline "Mathematics". Issues in the application of interactive forms in the study of mathematics are considered in works Cunska and Savicka (2012); (1) Lopez-Morteo and López (2007).

Technologies of interactive teaching are successfully used at studies in Mathematics: when fixing the studied material; when solving complex theoretical problems; when receiving various ways of solving problems. Examples of such work are: the analysis of a partner's written work, development of questions to the audience or answers to a teacher's questions, etc. One more variant of teaching, which is used for development of an ability 
to communicate in a group, an ability to convince and hold a discussion, is a method "two-four-all together". It is that learners are given a problem situation and 1-2 minutes to consider individual answers or decisions. Then students unite in couples and hold discussions of their ideas with each other. Then a teacher unites couples in the fours and a further search of an answer occurs, all the four must come to a common decision. Thus, it is possible to go on to a collective discussion of a question smoothly.

According to the curriculum 176 hours are given (including: 30 hours-lectures, 30 hours-a practical course, 80 hours-self-guided work, 36 hours-examination) for studying a discipline "Mathematics" in the fourth semester on two modules. For EER are given 48 hours (including: 12 hours-lectures, 12 hours-a practical course, 24 hours-self-guided work).

The study of the material in EER is carried out in parallel with full-time tuition. The studied material contains historical material and reveals the following subjects:

1) Ordinary differential equations and their solutions.

2) Differential equations with separable variables.

3) Homogeneous equations.

4) Linear equations of the first degree.

5) Total differential equations.

6) Solution of problems by means of the differential equations of the first degree.

\subsection{Structure of EER}

Each EER surely assumes availability of brief lecture notes, the material in which is structured by subjects. Each subject contains the following obligatory elements:

- full name of a subject;

- abstract of a subject;

- methodical recommendations on the study of a subject;

- recommended information resources with indication of concrete pages (for electronic educational manuals, monographs, etc.) or time intervals (for video and audio resources);

- list of abbreviations;

- glossary (short terminological dictionary-reference book on a subject);

- questions for study on a subject;

- summary of theoretical material on a subject: definition of the basic notions, formulation of the main results;

- questions and tasks for control of knowledge on a subject.

- Obligatory elements of brief lecture notes are:

- general list of abbreviations on a course in whole;

- general glossary (short terminological dictionary-reference book on a course in whole);

- general list of information resources;

- questions and tasks for final assessment.

The integral part of any EER is theoretical material the high-quality presentation of which forms a basis for organization of the educational process. For each separate subject of EER the lecture material consisting of a set of several pages is prepared. Transition to the following page assumes an answer to the set questions. Depending on the correctness of an answer a student goes on to the following page or comes back to the previous one. Lectures in EER, unlike the traditional classroom ones, exclude live communication with a teacher but, nevertheless, have a number of advantages. The use of the latest information technologies (hypertext, multimedia, virtual reality, etc.) makes lectures expressive and visual that points out to their interactivity.

For each lecture the practical tasks and methodical recommendations on their doing are developed. The practical studies in EER are an interactive form of studies. They are conducted by means of video conferences, allow to enter a discussion in any point of its development, to return on some steps back having read the previous statements. A teacher can assess master of material on the activity degree of a discussion participant. The number of interactions of students among themselves increases and a teacher acts as an equal in rights partner. 
Studying material of EER provides holding consultations by a teacher. Consultations in EER are one of the forms of management of learners' work and giving them help in independent study of a discipline. A telephone and e-mail and also a teleconference are used. Consultations help a teacher to assess a learner's personal qualities: intellect, attention, memory, imagination and thinking. Consultations can be held on a subject of the lecture material in the process of self-guided work or before examination, end-of-term test, seminar. Consultations can be individual and group, be held in the off-line and/or on-line mode. A student's main actions in preparation for a consultation include the following simple operations:

- formulation of a question to a teacher or an answer-message to the received task;

- $\quad$ key-in of an answer-message;

- choice and input of a teacher's address;

- $\quad$ sending message (answer, question, form of address, etc.) to a teacher.

Control in EER is a check of results of theoretical and practical master of the educational material by a learner. In EER the test control, including different types of questions and doing tasks of different levels of complexity on each studied subject, has proved its value and has won the recognition. The test control differs from other control methods (oral and written examinations, end-of-term tests, tests, etc.) in the fact that it represents the specially prepared control set of tasks allowing assessing learners' knowledge by means of statistical methods reliably and adequately quantitatively.

The main advantages of the test control application are:

- objectivity of the check results as every time availability of the predetermined standard of an answer (answers) leads to the same result;

- increase of effectiveness of the controlling activity from a teacher by increasing its frequency and regularity;

- possibility of automation of checking learners' knowledge including using computers;

- possibility of their use in systems of distance education.

To increase effectiveness of mastering materials the electronic educational resources include the additional material in the form of links to video lessons and video courses by specific discipline sections, electronic textbooks, links to the Internet sources. All additional materials are put in appropriate course sections in the form of separate files or links to the external sources.

\section{Results}

Filling EER with interactive technologies and its introduction in the educational process within full-time tuition allowed us to create the necessary volume of tasks for students' self-guided work; to accurately distribute it in a temporary context of a semester according to the curriculum making a student to do tasks throughout the semester, not only on the eve of session; to convey methodical recommendations on doing all tasks to each student; in due time to give consultative help to a student both in the on-line mode and in real time; to assess a student's self-guided work more objectively.

The studies, given with use of EER on the basis of application of distance and interactive forms of education, give an opportunity of constant but not episodic (according to the schedule) contacts of students with a teacher, provide flexibility and availability of the educational process, more accurate administration of the educational process, increase objectivity of assessment of students' knowledge what is confirmed by the Internet testing in Mathematics which is annually held at the end of each semester.

\section{Discussion}

In August, 2014 the representatives of the Open University of Great Britain visited KFU, who highly appreciated the experience of the University in the field of electronic learning-in particular, the created open Catalogue of electronic courses, developed by the teachers of KFU, used in support of full-time tuition and tuition by correspondence within programmes of the higher professional and additional education.

It was also noted by the delegation that KFU uses the learning management system LMS MOODLE successfully as a basis of organization of the educational process. This system allows to create methodically saturated full electronic courses including some tens of specialized components such as an object "lecture", tasks and tests of various types, forums, chats, glossaries, objects Hot Potatoes, etc., what provides high extent of educational interactivity, allows a teacher to monitor the educational trajectories of learners, to realize various methods of pedagogical design (https://e.kfu.ru/ru/pilotnyj-proekt/novosti/358-kazanskij-federalnyj-universitet-vykhodit-v- 
otkrytoe-obrazovatelnoe-prostranstvo).

\section{Conclusion}

As practice showed, the electronic educational resources using interactive technologies are popular both with the students of full-time tuition and tuition by correspondence, especially when studying difficult educational subjects, when a learner has an opportunity to listen to a teacher's explanation repeatedly, to return to not clear moments during work on individual tasks.

Such unusual kind of work causes interest from students as work with resources and different tools in on-line is absolutely natural for a modern student. They actively work, track the results of the work done, take part in the discussion of problematic issues at a forum, consult with a teacher.

However, creation of EER is a difficult work for a teacher connected with mastering new technologies, development and putting the educational and methodical material in LMS MOODLE, introduction of a course in the educational process, management of students' self-guided work in the virtual educational environment. Therefore, the development department of the KFU educational resources provides distance 24-hour training teachers on the programme "Theory and Practice of Using LMS MOODLE in Teaching".

The problems, raised in the article, require further study. In particular, a question of application of interactive forms of education when training masters in various directions has not been revealed though there are huge opportunities here. The Federal State Standards of training masters provide a large number of hours for self-guided work what gives wide opportunities for using EER and interactive technologies.

\section{References}

Andreyev, A. (2003). Distance Learning in System of Continuous Professional Education. Innovations in Education, 4.

Anisimova, T., \& Krasnova, L. (2013). Distance Learning as One of Interactive Forms of Specialists Training in Higher Education Institution. Collection of Scientific Works Sworld. Materials of the International Scientific and Practical Conference "Modern Trends of Theoretical and Applied Researches 2013". Odessa, $1(16), 78-81$.

Burns, M. (2011). Distance Education for Teacher Training: Modes, Models and Methods. Retrieved September 3, 2013, from http://www.idd.edc.org/resources/publications/modes-models-and-methods

Cunska, A., \& Savicka, I. (2012, December 24). Use of ICT Teaching-Learning Methods make School Math Blossom. Procedia-Social and Behavioral Sciences, 69, 1481-1488. http://dx.doi.org/10.1016/j.sbspro.2012.12.089

Educational Benefits of Online Learning. (1998). CalPoly.edu. Retrieved March, 29, 2013, from

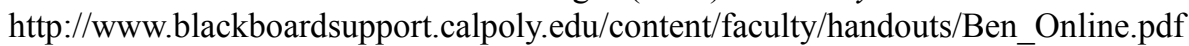

Fischer, N. (2010). Innovative Technologies in Professional Education. Bulletin of the Adyghe State University. Series 3: Pedagogics and Psychology, 1, 113-118.

Guschin, Yu. (2012). Interactive Methods of Teaching at the Higher School. Psychological Journal of the International University of Nature, Society and Person "Dubna", 2, 1-18.

Krasnova, L., \& Anisimova, T. (2013). Particularities of Remote-Acting Courses to Upgrade Teaching Qualification. World Applied Sciences Journal, 27 (Education, Law, Economics, Language and Communication), 158-161. http://dx.doi.org/10.5829/idosi.wasj.2013.27.elelc.33

Kurysheva, I. (2009). Classification of Interactive Methods of Teaching in the Context of Self-realization of Learners's Personalities. News of Herzen State Pedagogical University of Russia, 112, 160-164.

Lopez-Morteo, G., \& López, G. (2007, May). Computer support for learning mathematics: A learning environment based on recreational learning objects. Computers \& Education, 4(48), 618-641. http://dx.doi.org/10.1016/j.compedu.2005.04.014

Moore, M., \& Anderson, W. (2012). Handbook of Distance Education (2nd ed.). Psychology Press. Retrieved October 1, 2014, from http://www.books.google.ru/books?id=_IqeYfDpWGIC\&printsec=frontcover\&hl=ru \&source $=$ gbs_ge_summary_r\&cad $=0 \# \mathrm{v}=$ onepage $\& \mathrm{q} \& \mathrm{f}=$ false

Polat, E., Moiseyeva, M., \& Petrov, A. (2006). Pedagogical Technologies of Distance Learning. Moscow: Academy.

Reutova, E. (2012). Application of Active and Interactive Methods of Teaching in the Educational Process. 
Novosibirsk: Publishing house, NGAU.

Sarafanov, A., Sukovaty, A., Sukovataya, I. et al. (2006). Interactive Technologies in Distance Learning. Electronic Educational and Methodical Manual. Krasnoyarsk: IPTs KSTU.

Shaidullin, R., Safiullin, L., Gafurov, I., \& Safiullin, N. (2014, May 15). Blended Learning: Leading Modern Educational Technologies. Procedia-Social and Behavioral Sciences, 131, 105-110. http://dx.doi.org/10.1016/j.sbspro.2014.04.087

Sidenko, A., \& Khutorskoy, A. (2011). Distant Professional Development. National Education, 5, 79-86.

Soekartawi, H., \& Librero, F. (2002). Greater Learning Opportunities Through Distance Education: Experiences in Indonesia and the Philippines. Journal of Southeast Asian Education, 2(3), 283-320. Retrieved September 2, 2013, from www.seameo-journal.com/journal/index.php/education/article/viewFile/39/38

Stephens, D. (July 2007). Quality issues in distance learning. Retrieved September 6, 2013, from www.aacsb.edu/ /media/AACSB/.../wp-quality-issues-in-distance-edu.ashx

The Federal State Educational Standard of Higher Professional Education in the Training Direction 051000 "Professional Education" with Qualification (Degree) "Bachelor" \#781. (2009, December 22). Ministry of Education and Science of the Russian Federation. Retrieved September 25, 2014, from http://www.edu.ru/db/mo/Data/d_09/m781.html

Ustyugova, V. (2011). Student's Work in System of Distance Learning Moodle: Manual. Kazan, TSHPU.

\section{Copyrights}

Copyright for this article is retained by the author(s), with first publication rights granted to the journal.

This is an open-access article distributed under the terms and conditions of the Creative Commons Attribution license (http://creativecommons.org/licenses/by/3.0/). 